Jørgen Ulff-Møller Nielsen and Konrad Pawlik

The Export intensity of Foreign Affiliates in Transition Economies - the Importance of the Organization of Production

International Business Section 


\title{
The Export intensity of Foreign Affiliates in Transition Economies - the Importance of the Organization of Production
}

\author{
Associate professor Jørgen Ulff-Møller Nielsen \\ e-mail: jum a asb.dk \\ and \\ Ph.D. Student Konrad Pawlik \\ e-mail: kpa@asb.dk \\ Department of Management and International Business \\ Aarhus School of Business \\ Aarhus, Denmark
}

\begin{abstract}
On the basis of a unique database containing trade and industry variables of foreign owned companies in the Polish manufacturing industry for the years 1993-2002, this paper investigates the relation between the organizational structure of multinational enterprises (vertically or horizontally integrated) and the export structure of their affiliates. Labour intensity, import intensity and scale economies at industry level are shown to be important explanatory variables for foreign affiliates' export intensity well in accordance with the organizational structure of multinational enterprises. Specific transitional factors are shown also to be of importance with respect to the ability of affiliates to absorb knowledge, transferred from the parent companies.
\end{abstract}

Keywords: Export intensity; foreign affiliates; Poland; vertically and horizontally integrated MNEs; knowledge transfer; absorptive capacity

The paper was presented as competitive at the Academy of International Business Annual Conference in Quebec City, Canada, 2005. 


\section{Introduction}

Trade associated with multinational enterprises (MNEs) is estimated to account for about two thirds of world trade, and trade between parent company and affiliates (intra-firm trade) alone for one third (UNCTAD, 1999). To create foreign affiliates generally presupposes some ownership-specific advantages according to the OLI paradigm of Dunning (1988). These advantages may be transferred as knowledge from the parent company to the affiliate either embodied in intermediate and capital goods or disembodied that is, e.g. transferred as blueprints or through people as tacit knowledge (see Andersson and Fredriksson, 1996). The type of knowledge transfer - embodied or disembodied - may be closely related to the organizational form of foreign production - horizontally or vertically integration - a classification proposed by Caves (1971) and extensively used in the knowledge capital model of Markusen (2002). Horizontally integrated MNEs (HOR) are characterized by the creation of affiliates similar to the production plant in the home country with the purpose of selling solely in the host market. Vertically integrated MNEs (VER) on the other hand are characterized by splitting up the value chain and placing slices in countries in which factor endowment fits well with the factor requirement of the given production process. For this type of organization, export is assumed to be intensive between affiliates and the parent company. Embodied knowledge transfer, which is related to international trade in (physical) capital and intermediate goods may be assumed to be closely related to vertically integrated companies, in which case intermediate goods are sent from the plant in the parent country to the affiliate for further value adding activities. Disembodied knowledge transfer, on the other hand, seems more closely related to horizontally integrated MNEs, since a fully scaled production plant in this case is established in a foreign country requiring far reaching knowledge transfer. The organizational form of MNEs seems therefore to be highly relevant for the international trade pattern of foreign affiliates.

Empirical research on trade from affiliates of MNEs from developed countries making investments in other developed countries may be "biased" in the sense that these foreign direct investments are primarily of the horizontally integrated type. For transition economies, vertically integrated MNEs are on the other hand expected to be very important, because of their lower labour costs. Research on the export behaviour of affiliates of MNEs operating in transition economies may therefore create a basis for a widened understanding of the export behaviour of MNEs.

Empirical studies of affiliates of MNEs using international trade and investment theory are typically based on nationwide databases, primarily US data. Most of these studies treat all output by foreign affiliates in a given host country as destined for the local market (see Brainard, 1997; 
Markusen and Maskus, 2002; Slaughter, 2003; Yeaple, 2001; and Carr et. al., 2001). In other words, they look at the total sales of affiliates and try to explain it by using country and industry characteristics. Most of these studies support the view that the dominant motive of the MNEs is to go for markets (that is they are horizontally integrated). Andersson and Frederiksson (1996) is an important exception. Their research is based on trade from affiliates of Swedish MNEs using the organizational structure of MNEs (horizontally versus vertically integrated) as a main explanatory variable. Their conclusion based on observations for a three year period is that there is a strong correlation between vertical integration and export intensity.

In this paper, a unique database on industry variables for foreign owned companies in Poland 1993-2002 is used to investigate the export behaviour of MNEs affiliates in Poland. The organizational structure of the MNEs is - like in Andersson and Frederiksson (1996) - viewed as a decisive factor for the export behaviour of the affiliates. The organizational structure is furthermore supposed to be closely related to the type of knowledge transferred, embodied or disembodied, which may be related to the degree of control over the affiliate, using ideas from Teece (1977) and Kogut and Zander (1993). Poland is an attractive example of a transition economy for this type of research since a mix of horizontally (because of market size) and vertically (because of low wages) integrated MNEs is expected to operate there (see Nielsen and Pawlik, 2004). This paper is therefore expected to contribute to the (scarce) empirical literature on the export behaviour of foreign owned affiliates, with special reference to the case of a specific transition economy.

The paper is organized as follows. The next section presents the used theories of international organization of production, which are also the basis for making hypotheses for the size of export to sales ratio, the used measure for export intensity. The third section presents the used data and the empirical model. This is followed by a section presenting empirical findings, and the last section concludes.

\section{International organization of production and export intensity: hypotheses}

A solely horizontally integrated MNE operates with affiliates with production similar to that at home. The production of the affiliate is fully sold in the host country and export is per definition zero, and so is the export intensity - the export sales ratio. At the other extreme, we have a solely vertically integrated MNE with a slice of the value chain produced in the host country. In the knowledge capital model of Markusen (2002), this slice is exported back to the parent company for 
further value adding to the final product. None of the produced intermediate goods are therefore sold locally that is, all output is exported, and therefore the export intensity is one $(100 \%){ }^{1}$

Whether a horizontally or vertically integrated MNE is established is among other things dependent on the size of scale economies in the industry, trade costs between the investing country and the host country, the relative market sizes of the two countries and differences in production costs (factor endowments) and differences in factor intensities for the different parts of the value chain. Low scale economies at plant level, high trade costs between countries, equal market sizes and equal factor costs are all factors that increase the possibility for horizontally integrated MNEs to be established. Low factor costs in the host country, large differences in factor intensities for different slices of the value chain, low trade costs, and large economies of scale at plant level (for the given slice of the value chain) are on the other hand factors that increase the probability for vertically integrated MNEs to be created (see Markusen, 2002).

But in the "real" world, MNEs are very seldom solely horizontally or vertically integrated and therefore the export intensity of the affiliate may result in any value between zero and one, and the value may change over time. ${ }^{2}$ An extended form of a vertically integrated MNE is an export platform MNE, where the affiliate's output is (largely) sold in third markets rather than in the parent or host market (see Ekholm, Forslid and Markusen, 2003). The concept "export platform" may also be viewed as an extended type of horizontal integration, where the surrounding region, instead of just the host country, is viewed as the relevant market. This may be the case, where trade costs between host country and investor country are rather high, but trade costs between countries in the region are rather low, and where the market size of the countries in the region is sufficient to reap economies of scale.

A multi-product firm version of the horizontally integrated MNE does also result in an export intensity different from zero. This situation arises, where the MNE produces different imperfect substitutable varieties in different countries. The reason for this behaviour is that trade costs shield home produced varieties from a high revenue depressing effect of producing some new varieties abroad, so total MNE profit may increase. The domestic as well as the foreign produced varieties are sold in other countries than where the production takes place, so this type of MNE

\footnotetext{
${ }^{1}$ In the case, where an affiliate assembles intermediate goods (exported from the parent company) to a final good and exports this final good to customers in the home country as well as in other countries, the situation with respect to the size of the export intensity does not change (unless some of the final customers are in the host country).

${ }^{2}$ In Central and Eastern Europe many MNEs in the beginning focused on the local markets, but as these were saturated and also the productivity in the affiliated increased, they started exporting (Meyer, 2001; Nielsen and Pawlik, 2004).
} 
often has a high export share, both from home and from its affiliates (see Baldwin and Ottaviano, 2001).

Figure 1 gives a sketch of the assumed relation between export intensity and the organizational structures of MNEs.

Figure 1. Export intensity and organizational structure of multinational enterprises

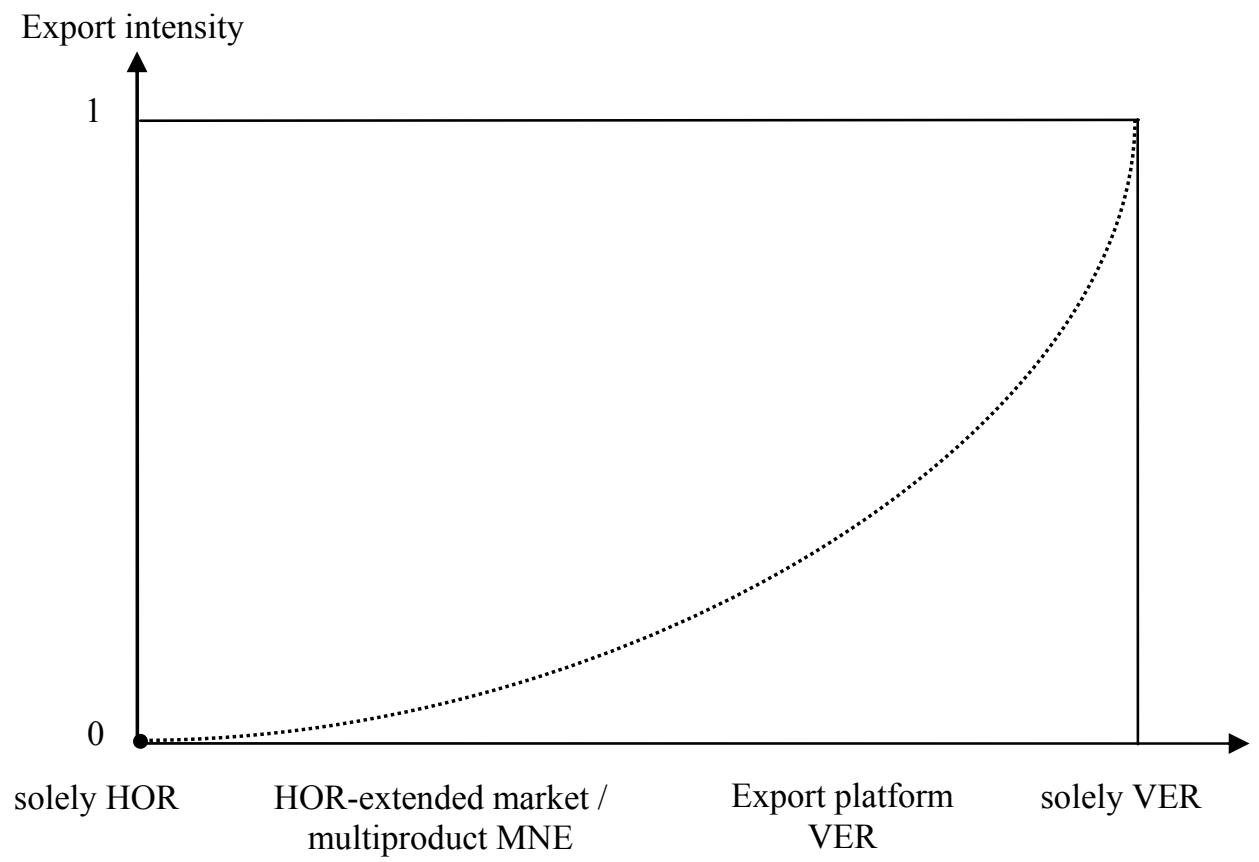

Notes: HOR- horizontally integrated MNE. VER-vertically integrated MNE.

Along the horizontal axis, the different organizational structures of MNEs, as discussed above, are indicated with solely horizontally and vertically integrated MNEs at the end points of the scale, and some more realistic intermediate types between the extremes. Along the vertical axes is the size of the export intensity of the affiliates (EXPORT), taking values between zero and one. When moving to the right in figure 1, we expect the export intensity to increase as indicated by the curve (with an unknown curvature).

Vertically integrated MNEs from high income countries, investing in emerging or transition economies, are looking for low wages, which may be exploited in labour intensive industries. The export intensity of affiliates is therefore expected to be positively related to the degree of labour intensity $(L A B)$ at the firm/industry level $\left(\mathbf{H}_{\mathbf{1}}: \delta E X P O R T / \delta L A B>0\right)$.

Affiliates from vertically integrated MNEs import (source) intermediate goods from the parent company for further value adding activities. This import is assumed to be one of the primary 
channels for transferring (embodied) knowledge to the affiliate (Andersson and Frederiksson, 1996). Transfer of embodied knowledge may be through both intra-firm trade and through market transactions, but there are good reasons to expect the intra-firm component of total affiliate imports to be rather important. Vertically integrated affiliates are anyway assumed, to a larger extent than horizontally integrated affiliates, to be dependent on imports that is, the affiliates' import intensity is viewed to be a good proxy for the degree of vertical integration $\left(\mathbf{H}_{2}: \delta E X P O R T / \delta I M P O R T>0\right)$.

For horizontally integrated MNEs, knowledge transfer is expected to be relatively more of the disembodied type related to non-physical goods such as blueprints and tacit knowledge that is, "knowledge that is difficult to understand and codify" (Kogut and Zander, 1993). Generally, such knowledge is not easily transferred, but a (fully owned) MNE has some relative efficiency advantages over the market (and different types of intermediate ownership, such as joint ventures, licensing etc.), and therefore the MNE's degree of control over the assets of the affiliates (CONT) is assumed to be higher for horizontally than for vertically integrated affiliates $\left(\mathbf{H}_{3}\right.$ : $\delta E X P O R T / \delta C O N T<0)$.

Following this type of reasoning, there may also be a demand for a higher level of absorptive capacity of knowledge at the affiliate level in horizontally integrated affiliates (Cohen and Levinthal, 1990). ${ }^{3}$ Since absorptive capacity of an organization depends on the absorptive capacities of its individual members, it may be increased trough human resource management, e.g. through human capital investments and different wage incentive systems or through expatriates. Horizontally integrated affiliates (low export intensive industries) are therefore expected to pay

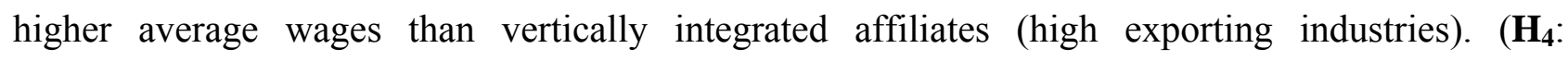
$\delta E X P O R T / \delta / W A G E<0)$.

For affiliates of the vertically integrated type, investments (and technological renewals) are typically supposed to be relatively (to sales) small, since the initial capital plant may have been shipped from home and all technological improvements done in the parent company. In a horizontally integrated affiliate on the other hand, a parallel plant to that of home has to be built, typically involving a huge investment (fixed costs). In a dynamic setting, investments are typically related to installing newer vintages of machinery, and since the view of this paper is that horizontally integrated affiliates are technologically more advanced, than vertically integrated ones, a high investment ratio is supposed to be associated primarily to the first type of organization. A

\footnotetext{
${ }^{3}$ Cohen and Levinthal (1990: 128) define 'absorptive capacity' as “ [... the ability of a firm to recognize the value of new, external information, assimilate it, and apply it to commercial ends [..].
} 
negative relation between the export intensity and the investment intensity is therefore expected $\left(\mathbf{H}_{5}: \delta E X P O R T / \delta / I N V E S T<0\right)$.

Given the characteristics of horizontally integrated MNEs - that it is profitable to build a full scaled plant in the host country - economies of scale (size) at plant level (in the investor or the host country) are expected to be relatively small in these industries. For vertically integrated MNEs, on the other hand, some economies of scale and/or relatively big differences in factor intensities are a necessary requirement for this type of investment $\left(\mathbf{H}_{6}: \delta E X P O R T / \delta S C A L E>0\right) .{ }^{4}$

Because of the gradual opening of the Polish economy over the investigated period (19932002) that ended close to the Polish EU membership, a gradual general increase in the export intensity is expected $\left(\mathbf{H}_{7}: \delta E X P O R T / \delta T I M E>0\right)$.

The first six hypotheses are based on theoretical considerations, not specifically related to a transition economy like the Polish one. They may therefore fail an empirical test, since specific transitional factors, like the chosen privatization and restructuring paths, may go counter to the theoretical explanations given above. If they don't fail, it may indicate that the theoretical background used in this paper is robust and valid also for transition economies. If the empirical tests on the other hand fail with respect to a number of our hypotheses, there are reasons to reconsider the theoretical background, when used to transition economies, and look for supplementary transitional factors.

\section{Data and methodology}

As explained above, the dependent variable is the export intensity of affiliates (EXPORT) that is exports divided by sales. Because of confidentiality reasons, the used data (as described below) do not give any possibility to distinguish to which countries exports are flowing (and from which countries imports are coming). Exports are therefore the multilateral exports from affiliates in Poland (both to the parent company and elsewhere). The exports of affiliates may therefore not be explained by country variables, only industry variables are used. The export intensity is explained by the following industry variables (compare the above hypotheses):

- Import intensity (IMPORT), as an indicator for international sourcing in an industry, measured by the import value divided by sales,

\footnotetext{
${ }^{4}$ This hypothesis assumes comparable trade barriers in horizontally and vertically integrated industries. In case of very high trade barriers, the establishment of e.g. a horizontal affiliate may be profitable, even when economies of scale are high.
} 
- Foreign control (CONT), as a measure for the extent to which MNEs control disembodied knowledge transfer to their affiliates, measured by the foreign capital share that is, foreign owners' input of capital as a part of total capital provided for setting up their business entities,

- Labour intensity ( $L A B)$, as a measure for the amount of labour relative to other factors of production in an industry, measured by the number of employees per real sales unit ${ }^{5}$,

- Wage level (WAGE), as a measure for the absorptive capacity at the affiliate level in an industry, measured by expenditure on real salaries, regardless of type of work in number of employees,

- Scale economies/size of affiliate (SCALE), measured by the average size of establishment in an industry (real sales divided by number of companies),

- Investment-to-sales ratio (INVEST), captures all expenditures on fixed assets in an industry: intangible and tangible as a share of revenues on sales.

A scatter-plot of all combinations of variables is shown in the appendix as figure A1 and in tables A1-A3 correlation coefficients between all variables for the whole period and for two subperiods are given.

To control for macroeconomic shocks (privatization, trade liberalization etc.) time dummies (TIME -1994 to 2002) are used.

The resulting regression model is the following:

$$
E X P O R T_{i, t}=\beta_{0}+\beta_{1} L A B_{i, t}+\beta_{2} I M P O R T_{i, t}+\beta_{3} C O N T_{i, t}+\beta_{4} S C A L E_{i, t}+\beta_{5} W_{A G E_{i, t}}+\beta_{6} I N V E S T_{i, t}+T I M E+\epsilon_{i, t}
$$

with $i$ indicating a NACE 3-digit manufacturing industry, $t$ time (1993-2002), $\epsilon_{i, t}$ the error term and signs below the explanatory variables the sign of the expected relationships.

The data rest on a unique database created in cooperation with the Central Statistical Office of Poland. This database includes information on all foreign companies with more than 9 employees and with a foreign capital share equal to or greater than 10 percent in total equity. From this database, export and import data, sales value, wages, investments, number of companies and employees, and foreign capital share are used. All variables are measured at 3-digit manufacturing NACE industry level. Because of confidentiality reasons, information is only accessible at 3-digit

\footnotetext{
${ }^{5}$ We have alternatively used basic capital divided by the amount of labour, but with less success.
} 
NACE industry level, if the number of foreign companies is three or more. No export intensities take the value of zero, which is related to the rather aggregated industry level that is used. In Nielsen and Pawlik (2004) a more detailed explanation of the database is given. ${ }^{6}$

\subsection{Techniques of estimation}

Because the data set has both a cross-sectional (approximately 80 industries) and a time series dimension (10 years), to increase the sample size, a pooled cross section analysis over 10 years has been carried out giving 755 observations. Panel data analysis has also been done to account for possible heterogeneity across manufacturing industries. This estimation technique assumes that the intercept $\left(\beta_{0}\right)$ in equation (1) varies across industries and can thus be written as $\beta_{0 \mathrm{i}} \beta_{0 \mathrm{i}}$ captures all unobserved, time-constant factors that affect $E X P O R T_{i, t}$. The regression equation using both a fixed and a random effect model is estimated. The first assumes $\beta_{0 \mathrm{i}}$ to be a fixed parameter and allows for arbitrary correlations between $\beta_{0 \mathrm{i}}$ and the independent variables in any time period, while the latter is attractive to use, when the unobserved effects are thought to be uncorrelated with all explanatory variables (Woolridge, 2003).

Because there are good reasons to expect that $\beta_{0 \mathrm{i}}$ is correlated with some of the explanatory variables like e.g. labour intensity $(L A B)$, fixed effect panel estimations are first made and an F-test used to figure out if there is a fixed effect (unobserved heterogeneity). Because the unobserved heterogeneity as mentioned may also exist in case of random effect, the Breusch and Pagan Lagrangian multiplier test (LM), is used for random effects. If unobserved heterogeneity is found in both the F-test and the LM-test the Hausman-test is used to compare fixed and random effect (null hypothesis that random effect model is valid). Both log-log models as well as level-log models are estimated.

\footnotetext{
${ }^{6}$ Here is it also shown and explained, why in a number of cases the export intensity is larger than one, and the consequences of this fact.
} 


\section{Results}

\subsection{Export and import intensities}

To get an impression of the size of export and import intensities and to make a preliminary evaluation of hypotheses $\mathrm{H}_{1}, \mathrm{H}_{2}, \mathrm{H}_{6}$ and $\mathrm{H}_{7}$, table 1 presents numbers for export and import intensities across factor intensity industries following the OECD (2001) classification dividing industries into resource intensive, labour intensive, scale intensive, specialized supplier and science based industries.

Not surprisingly, the export intensity for all economic sectors is smaller than for just manufacturing, which also shows a larger growth over 1993-2002 (indication of a confirmation of $\mathrm{H}_{7}$ ). Looking at factor intensity differences, expectations are confirmed in the sense that labour intensive industries like production of e.g. textiles, apparel, leather and furniture have the highest and a very stable level of export intensity around 70-80 percent (indication of a confirmation of $\mathrm{H}_{1}$ ). The slightly decline may be an indication of a change from solely vertically integrated affiliates to more export platform type of integration, where exports instead of only flowing to the investor country also flow to the region, including partly to the host country, for which reasons the export intensity falls. Similarly, high import-intensities exist for labour-intensity industries, indicating that labour-intensive industries are vertically integrated (indication of $\mathrm{H}_{2}$ ). The larger decrease in imports (sourcing) than in exports for these industries may be an indication of local sourcing possibilities having evolved somewhat over the years 1993-2002, because, in the more mature transition phase, local companies (foreign or privately owned) have been established and have learned to produce high quality intermediates. Scale intensive industries, like production of e.g. pulp and paper, rubber, basic iron and motor vehicles have shown the highest growth in export as well as in import intensity and end up at a level of fifty percent (indication of $\mathrm{H}_{6}$ ). 
Table 1. Export and import intensities for foreign capital in Poland 1993-2002 across factor intensity industries

\begin{tabular}{|c|c|c|c|c|c|c|c|c|c|c|c|}
\hline Description / Year & 1993 & 1994 & 1995 & 1996 & 1997 & 1998 & 1999 & 2000 & 2001 & 2002 & $\Delta$ \\
\hline Export intensity for Total Economy ${ }^{1}$ & 0.15 & 0.19 & 0.20 & 0.16 & 0.17 & 0.16 & 0.16 & 0.18 & 0.19 & 0.21 & 0.06 \\
\hline $\begin{array}{l}\text { Export intensity: 3-digit } \\
\text { manufacturing industries }\end{array}$ & 0.24 & 0.31 & 0.32 & 0.25 & 0.26 & 0.28 & 0.30 & 0.38 & 0.35 & 0.39 & 0.15 \\
\hline Resource intensive & 0.22 & 0.25 & 0.25 & 0.17 & 0.18 & 0.18 & 0.18 & 0.17 & 0.18 & 0.18 & -0.04 \\
\hline Labour intensive & 0.82 & 0.81 & 0.88 & 0.77 & 0.71 & 0.72 & 0.75 & 0.74 & 0.78 & 0.78 & -0.04 \\
\hline Scale intensive & 0.11 & 0.25 & 0.27 & 0.21 & 0.22 & 0.24 & 0.29 & 0.46 & 0.53 & 0.53 & 0.42 \\
\hline Specialized supplier & 0.34 & 0.33 & 0.39 & 0.40 & 0.46 & 0.50 & 0.50 & 0.60 & 0.63 & 0.63 & 0.29 \\
\hline Science based & 0.05 & 0.07 & 0.10 & 0.14 & 0.10 & 0.12 & 0.12 & 0.15 & 0.29 & 0.29 & 0.24 \\
\hline Import intensity for Total Economy ${ }^{1}$ & 0.26 & 0.31 & 0.34 & 0.31 & 0.33 & 0.30 & 0.31 & 0.32 & 0.30 & 0.29 & 0.03 \\
\hline $\begin{array}{l}\text { Import intensity: 3-digit } \\
\text { manufacturing industries }\end{array}$ & 0.28 & 0.37 & 0.38 & 0.34 & 0.37 & 0.36 & 0.36 & 0.39 & 0.37 & 0.38 & 0.10 \\
\hline Resource intensive & 0.23 & 0.25 & 0.27 & 0.21 & 0.21 & 0.21 & 0.20 & 0.23 & 0.23 & 0.23 & 0.00 \\
\hline Labour intensive & 0.75 & 0.65 & 0.74 & 0.68 & 0.69 & 0.65 & 0.67 & 0.62 & 0.64 & 0.64 & -0.11 \\
\hline Scale intensive & 0.19 & 0.40 & 0.41 & 0.39 & 0.45 & 0.42 & 0.46 & 0.46 & 0.47 & 0.47 & 0.28 \\
\hline Specialized supplier & 0.39 & 0.44 & 0.47 & 0.48 & 0.47 & 0.45 & 0.46 & 0.49 & 0.50 & 0.50 & 0.11 \\
\hline Science based & 0.38 & 0.39 & 0.30 & 0.43 & 0.42 & 0.46 & 0.47 & 0.52 & 0.55 & 0.55 & 0.17 \\
\hline
\end{tabular}

${ }^{\mathrm{I}}$ Total economy is besides manufacturing industries, services etc.

Notes: $\Delta$ : Growth in percentage points from 1993 to 2002.

Source: Own calculations based on data from GUS.

For the first half of the period 1993-2002, specialized supplier industries like e.g. production of machinery and communication equipment have higher import intensity than export intensity, while the opposite happens after 1998. Goods from these industries are investment goods used in the foreign companies as well as in domestic privately owned companies. Through such goods, embodied knowledge/technology may be transferred also to other industries. For science based industries like e.g. production of pharmaceuticals, computers, and medical instruments, the import intensity is found to exceed the export intensity significantly, with the latter at a rather low - but increasing - level. Foreign affiliate production in these advanced industries is clearly oriented to the host market, seemingly fitting the horizontal type of MNE organization. The high level of import intensity for these technologically sophisticated types of goods may partly be viewed as embodied knowledge transfer within MNEs, as a mean to protect dissemination of knowledge outside the companies (seemingly in contradiction to $\mathrm{H} 2$ ). When comparing the development of export intensities over time for the different factor intensities (decrease for labour intensity and increase for the others), there seems to be a convergence of the export intensities to a high level, with resource intensive industries as an exception.7

\footnotetext{
${ }^{7}$ The standard deviation of the export intensity variable across 3-digit NACE industries has decreased from 1993 to 2002 .
} 


\subsection{Regression results}

The pooled (OLS) regressions are rejected in favour of the fixed effects and the random effects regressions, so unobserved heterogeneity exists. According to the Hausman specification test, random effect is not favoured, since some regressors are correlated with the unobserved heterogeneity term, but anyhow the difference between random and fixed effects estimators is small. Since the log-log models perform better than (or equal to) level-log models table 2 only presents the log-log fixed effect models.

Looking first at the last column, which shows results for the whole period of analyses (1993-2002), the power of explanation of $37 \%$ is reasonable high, when it is taken into consideration that only industry and no country variables are used as explanatory variables. Import intensity, labour intensity and invest-to sales ratio are significant at least at a $1 \%$ level, all with the expected signs. Scale economies, wage level and foreign control are all significant at least at a 10\% level (8, 9 and 10\% respectively), but with $W A G E$ and CONT having the wrong signs. Labour intensity contributes to the largest extent to the explanation of the export intensity with an elasticity close to 0.7 , but also the import intensity has a relative high elasticity $(0.5)$.

The fact that scale economies (or the size of affiliates) are positively associated to their export performance is also supported by Andersson and Frederiksson (1996). When looking at export companies generally (and not just foreign affiliates), a number of theoretical arguments found in export marketing literature also support a positive relation between size and export intensity, while empirical findings have been mixed, see Bonaccorsi (1991) for a review of theoretical arguments and some (older) empirical evidence. Looking specifically at foreign subsidiaries Egelhoff et al. (2000) found a positive relation for foreign affiliates in Ireland. 
Table 2. Estimation results - fixed effect panel estimations

\begin{tabular}{|c|c|c|c|c|c|c|}
\hline \multirow{3}{*}{$\begin{array}{l}\text { (Constant) } \\
\end{array}$} & \multicolumn{2}{|c|}{ 1993-1997 } & \multicolumn{2}{|c|}{ 1998-2002 } & \multicolumn{2}{|c|}{ 1993-2002 } \\
\hline & \multicolumn{2}{|c|}{$\beta \quad t$-test } & \multicolumn{2}{|c|}{$\beta \quad t$-test } & \multicolumn{2}{|c|}{$\beta \quad$ t-test } \\
\hline & 0.76 & 1.83 & $1.24 *$ & 1.96 & $0.88 * *$ & 2.79 \\
\hline $\ln (W A G E)$ & 0.36 & 1.85 & $-0.33 * * *$ & -3.47 & 0.18 & 1.69 \\
\hline $\ln (L A B)$ & $0.71 * * *$ & 7.23 & $0.29 * *$ & 2.68 & $0.71 * * *$ & 9.93 \\
\hline $\ln (S C A L E)$ & 0.00 & 0.13 & -0.02 & -0.29 & 0.05 & 1.73 \\
\hline$\sigma 1994$ & $0.29 *$ & 2.46 & & & 0.15 & 1.87 \\
\hline$\sigma 1995$ & $0.29 * * *$ & 3.58 & & & $0.25 * *$ & 3.12 \\
\hline$\sigma 1996$ & $0.29 * * *$ & 3.42 & & & $0.25 * *$ & 3.06 \\
\hline$\sigma 2000$ & & & $0.30 * * *$ & 5.65 & $0.50 * * *$ & 4.84 \\
\hline$\sigma 2001$ & & & $0.46 * * *$ & 7.33 & $0.60 * * *$ & 5.31 \\
\hline$\sigma 2002$ & & & $0.50 * * *$ & 8.72 & $0.70 * * *$ & 6.88 \\
\hline $\mathrm{R}^{2}$ (within) & \multicolumn{2}{|c|}{0.35} & \multicolumn{2}{|c|}{0.34} & \multicolumn{2}{|c|}{0.37} \\
\hline $\mathrm{N}$ & \multicolumn{2}{|c|}{359} & \multicolumn{2}{|c|}{396} & \multicolumn{2}{|c|}{755} \\
\hline $\begin{array}{l}\mathrm{F}\left(\mathrm{H}_{0}: \beta_{0,1}=\beta_{0,2}=\beta_{0,3}=\ldots \beta_{0, \mathrm{n}-1}=0, \mathrm{n} \text { number of }\right. \\
\text { entities })\end{array}$ & \multicolumn{2}{|c|}{$16.16^{* * *}$} & \multicolumn{2}{|c|}{$23.12 * * *$} & \multicolumn{2}{|c|}{$20.68 * * *$} \\
\hline Hausman & \multicolumn{2}{|c|}{$44.12 * * *$} & \multicolumn{2}{|c|}{$24.53 * *$} & \multicolumn{2}{|c|}{$94.76^{* * * *}$} \\
\hline
\end{tabular}

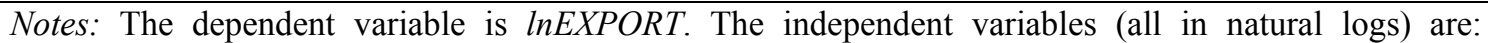
IMPORT: Import intensity. WAGE: The wage level. LAB: Labour intensity. INVEST: Investment activity. CONT: Foreign control, SCALE: Scale economies. $\sigma 1994, \sigma 1995$ etc. indicates time dummies, $N$ : Number of observations. ${ }^{*}, * *, * *$ significant at $5 \%, 1 \%$, and $0.1 \%$ levels.

There may be a number of reasons, why the association between control over affiliates and the export intensity has the opposite sign of what could be expected. The first reason may be that the hypothesis is generally incorrect (for market economies as well as for transition economies). Andersson and Frederiksson (1996) in their paper did also expect a negative relation, but found it to be insignificant. ${ }^{8}$ UNCTAD (1999) argues on the other hand that vertically integrated MNEs prefer their export-oriented affiliates to be highly controlled since their marketing knowledge is viewed as the important proprietary asset. This view may be correct, all else equal, but it seems to have a partial focus on a specific type of knowledge and do not take into consideration the necessity for different degrees of control across different types of important proprietary assets. Aggarwal (2002) and Siddhartan and Nollen (2004) argue also for a positive relation, using the same argument as in this paper. Their empirical evidence on MNEs in India supports to some extent their hypothesis, but the Siddahartan and Nollen study is delimited to information technology firms. Generally, besides

\footnotetext{
${ }^{8}$ But, when excluding a variable for the number of countries in which the MNE has manufacturing affiliates (a variable that is highly correlated to the control variable), the control variable becomes significantly negative (Andersson and Frederiksson, 1996:258).
} 
Andersson and Frederiksson (1996), these other studies are not related to alternative types of organizations, as the present study.

The second reason may be related to the statistical distribution of the CONT-variable. As shown in figure 2, the value of CONT is minimum 0.10 and maximum 1.00. The distribution across all 755 observations is skewed to the right with around $90 \%$ of the observations above $50 \%$. If "full control" over a company is defined as a foreign capital share above $50 \%$, it is obvious that full control is the "norm". If "full control" is defined as a foreign capital share of $100 \%$ (since only in this case, dissemination of important knowledge to other companies is minimized) this happens only in around $10 \%$ of the cases. In both situations, there will be very little variation in "control" or "non-control". On the other hand, looking at CONT as a continuous variable, as in this paper, seems appropriate, because data in this study are industry averages. A foreign capital share of 0.6 for a given industry in a given year may at the firm level consist of e.g. the following values $0.3 ; 0.3 ; 0.9$; 0.9 that is two foreign companies with "high" control and two with "little control". Therefore, the continuous variable approach in this study was supposed to make sense.

Figure 2. Distribution of foreign capital share across NACE 3-digit industries and the years 19932002

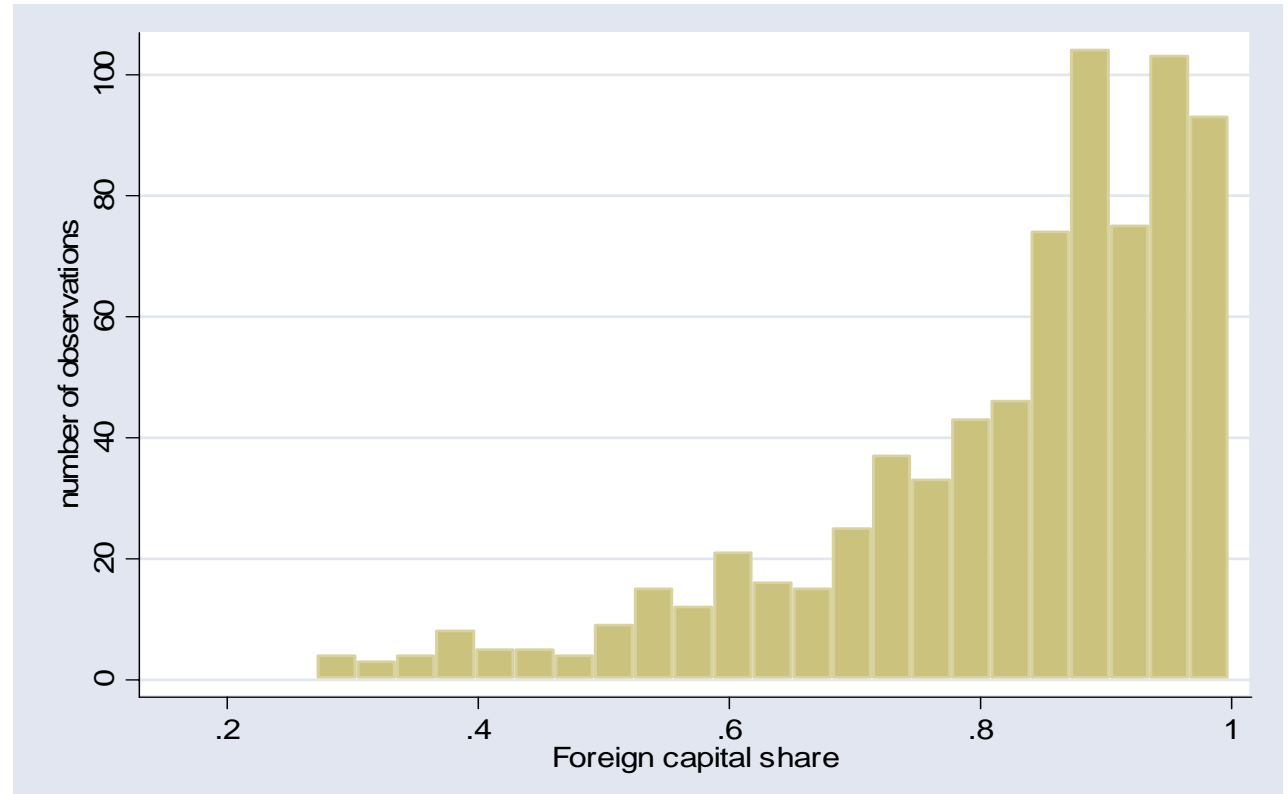

Source: own calculation.

A third reason may be more related to transition economy factors. Poland has often been characterised as a transition economy that did follow a shock therapy (Paldam, 2002). It does not follow from this that Poland from day one changed all rules/institutions from a planned economy to a market economy. Privatisation and restructuring of industries took some years and joint ventures 
and other types of lower control entry modes were more predominant in the beginning of the period 1992-2002 than later on. ${ }^{9}$ Figure 3 has divided 1993-2002 into two sub-periods to observe differences in control, and the regressions in table 2 are also examined for the two sub-periods.

Figure 3. The cumulative distribution of foreign capital share across NACE 3-digit manufacturing industries for the years 1993-1997 and 1998-2002

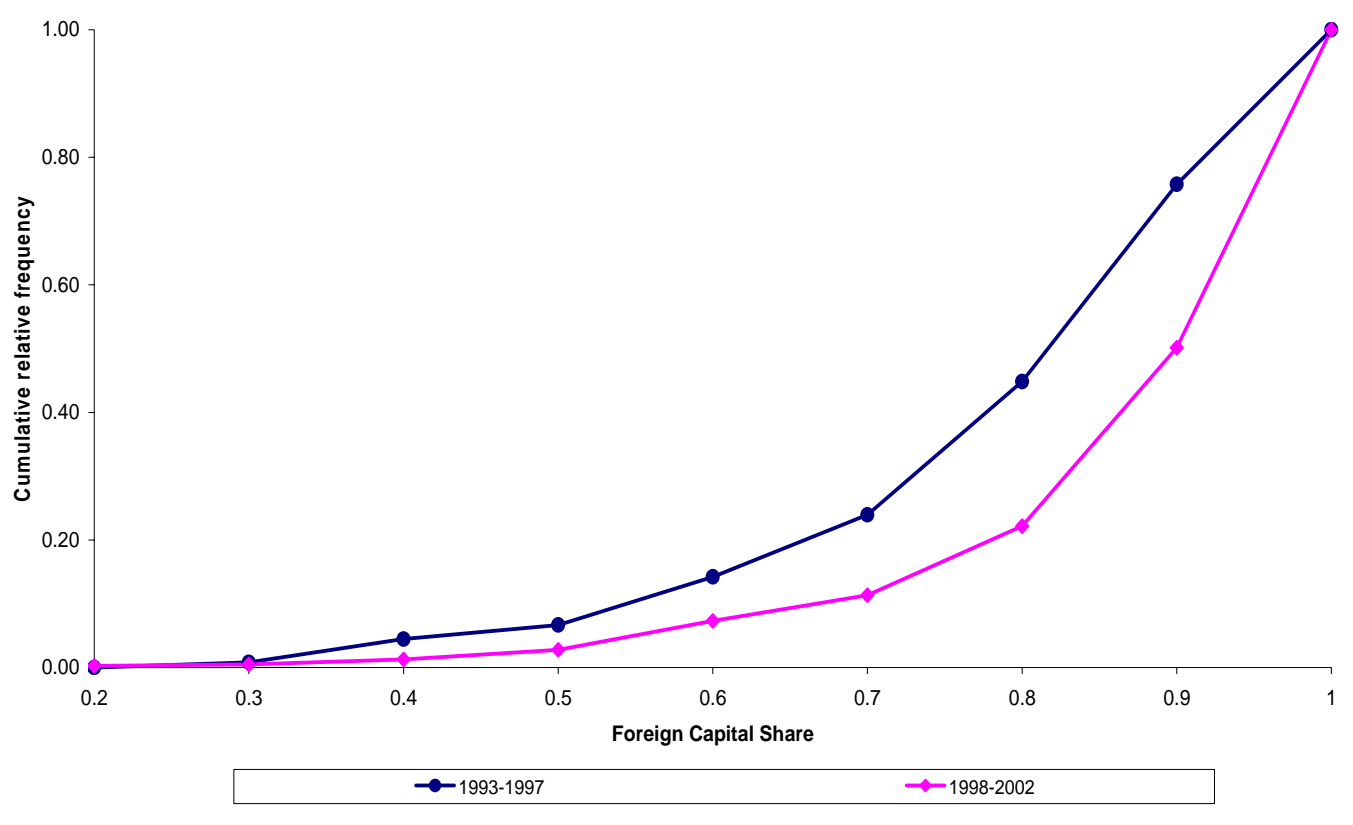

Source: own calculation.

Figure 3, demonstrates that the first half of the investigated period has a higher number of observations with lower control, compared to the more mature transition period (1998-2002). To the extent that this fact is related to transitional factors and not to the unconstrained optimal choice of MNEs, low exporting affiliates (HOR) may e.g. in some cases be related to low control levels, blurring the relation between export intensity and control, especially in the first half of the investigated period. ${ }^{10}$ This phenomenon is found in table 2 , where the association between control and export intensity for 1993-1997 is insignificant, but since the relation for the second period has an even stronger positive association (the elasticity has increased from 0.19 to 0.30 ), we have to reject hypothesis 3, based on the data of this paper. More refined measures for foreign control may improve the results / confirm the hypothesis.

\footnotetext{
${ }^{9}$ In the early 1990s, a JV was the only legally permissible model to establish a direct investment in most CEEC countries, but by 1992, FDI was fairly unregulated in most countries (Meyer, 2001).

${ }^{10}$ This "constrained" entry mode may of course also influence the association between the export intensity and some of the other variables.
} 
The positive partial association - though only significant at a 9\% level - between the export intensity and the wage level for the period 1993-2002 may be related to the fact that vertically integrated affiliates are highly dependent on skilled and high paid marketing people. Furthermore, the reason may be that this type of organization of production is dependent on production staff that knows a great deal about quality management systems etc. necessary for making products of a reasonable high quality standard, so they may compete in international markets. ${ }^{11}$ The relation between absorptive capacity and the type of organization of the MNE may therefore be more multifarious than expressed in hypotheses $\mathrm{H}_{4}$. Other researchers like e.g. Aggarwal (2002) do assume a positive relation between skills (and therefore also wages) and export performance.

The behaviour of the wage variable across the two sub-periods is interesting. For the second period, an expected negative and significant sign is found, while in the first period, the sign is positive and only slightly significant (7\%). Transitional factors may play a role here. In the beginning of the transition period, buying privatized public owned companies did put some restrictions on the buyer. The Polish government often established an agreement with the buyer not to lay off labour from day one. For that reason, there was established a temporary excess supply of labour in some of the foreign owned companies. Attraction of new high skilled and high paid staff and/or establishing different in-house human capital programs was therefore not the first point on the agenda for the newly established foreign owned companies. Later on, when constraints on staffing was lessened or eliminated, it became more important for foreign companies to combine staffing policy with the purpose of protecting specific valuable assets transferred from the parent company (or maybe sizeable transfer of complex knowledge first took off here?). ${ }^{12}$ Furthermore the total amount of FDI and the total level of affiliate activity (real sales and employment) increased significantly over time, creating an increased demand for skilled people, especially in industries, where protection of embodied knowledge was important. On the other hand, supply of the required specific competencies could not be established in the short run, i.e. because the required new skills are often based on tacit know-how, which requires an interactive learning process (Meyer, 2001). Therefore, the skill premium increased (Otte, 2003) with the effect that the average wage level in especially horizontally integrated (low exporting) industries increased. We may therefore conclude

\footnotetext{
${ }^{11}$ Generally, Poland has had a comparative advantage in intermediate technical skills, while managerial skills were deficient (Meyer, 2003).

${ }^{12}$ The downturn in the Polish business cycle 1999-2002 created a further pressure for internal rationalization, by reducing possible overstaffing.
} 
that the absorptive capacity explanation for the export intensity seems to be confirmed for the second more "normal" period (1998-2002).

You may argue that the rejection of hypothesis $\mathrm{H}_{3}$ (the influence of CONT on EXPORT) should also lead to a rejection of hypothesis $\mathrm{H}_{4}$ (the influence of WAGE on EXPORT), since both hypotheses are based on the view that knowledge is transferred from the parent company to the affiliate and that knowledge has different characteristics, so there are different requirements to the control of knowledge transferred (avoiding dissemination through different degrees of internalization) $\left(\mathrm{H}_{3}\right)$ and to the ability to absorb knowledge at the affiliate level $\left(\mathrm{H}_{4}\right)$. As stated above, it is our view that the CONT data are not sufficiently good to test $\mathrm{H}_{3}$. On the other hand, the confirmation of the hypothesis for the absorptive capacity for the second period may be viewed also as an indirect confirmation of the hypothesis on control of knowledge, since i.e. the wage data has a higher variance.

For the investment activity, we find significance with the expected sign for the first period, but not for the second period, but anyway significance and the expected sign for the whole period. As mentioned above and as documented in Nielsen and Pawlik (2004), there has over time been an increase in the general level of export intensity, but at the same time a decrease in the standard deviation of export intensities. This indicates that industries with a low export intensity in the beginning of the period have a higher level by the end, and the opposite for the high export intensity industries. In other words, there has been a move away from "pure" horizontally and vertically integrated affiliates towards more intermediate types, as shown in figure 1. A multinational enterprise that e.g. in 1993 established an affiliate in Poland with the aim solely to cover the domestic Polish market and to that purpose made huge investments, may later on, when it feels that the market in Poland has saturated, start exporting to the surrounding countries, so that the export intensity increases from zero to a positive value. It is fair to regard this affiliate as horizontally integrated, but with a changed definition of the "host market" to include some other countries in the region. Similarly, a solely vertically integrated affiliate, which in e.g. 1993 has an export intensity equal to one, may later on after learning and experiences with the local market start some local sales (the export intensity drops) and it then becomes a mix of a horizontally and vertically integrated affiliate. Such changes may reduce the partial association between export intensity and the investment level or even as is the case in table 2, eliminate the significance of the relation. 


\section{Conclusions}

This paper adds to the very limited literature on export intensity of MNE affiliates: First of all, by using the organizational structure of MNEs (vertically or horizontally integrated) taken from international economics (Caves, 1991, and Markusen, 2002) as a theoretical frame for explanation of the export intensity. Secondly, by adding elements from management and international business research (Cohen and Levintahl, 1990, and Kogut and Zander, 1993). Thirdly, by looking at a large transition economy like Poland, where both the market size and the labour costs may be of importance for the decision of MNEs in relation to establish affiliates there. Fourthly, by using a unique database on industry variables for foreign owned companies in Poland for as long a period as 1993-2002.

Neither labour intensity, import intensity, scale economies, investment activity nor wagelevel (absorptive capacity) may be excluded as possible explanatory variables for the export intensity of foreign affiliates in Poland, well in accordance with the organizational structure of MNEs. Only the degree of foreign control over its affiliate is not confirmed as an explanation, which probably is a result of either the used data for foreign control or specific transitional factors or both, and should therefore not be viewed as a general attack on the used theoretical background. Further research could clarify this relation. 


\section{References}

Aggarwal, A. (2002). 'Liberalisation, multinational enterprises and export performance: Evidence from Indian manufacturing', Journal of Development Studies, 38 (3), pp. 119-37.

Andersson, T. and Frederiksson, T. (1996). 'International organization of production and variation in exports from affiliates', Journal of International Business Studies, 27 (2), pp. 249-63.

Baldwin, R. E. and Ottaviano, G. I. P. (2001). 'Multiproduct multinationals and reciprocal FDI dumping', Journal of International Economics, 54, PP. 429-448.

Bonarccorsi, A. (1992). 'On the relationship between firm size and export intensity'. Journal of International Business Studies, 23 (4), pp. 605-635.

Brainard, S. L. (1997). 'An empirical assessment of proximity-concentration trade-off between multinational sales and trade', American Economic Review, 87, pp. 520-544.

Carr, D. L., Markusen, J.R. and Maskus, K. E. (2001). 'Estimating the knowledge-capital model of the multinational enterprise', American Economic Review, 91, pp. 693-708.

Caves, R. E. (1971). 'International corporations: The industrial economics of foreign investment', Economica, February, pp. 1-27.

Cohen, W. M. and Levintahl, D. A. (1990). 'Absorptive capacity: A new perspective on learning and innovation'. Administrative Science Quarterly, 35 (1), pp. 128-152.

Dunning, J. H. (1988). Explaining International Production. Unwin Hyman. London.

Egelhoff, W. G., Gorman, L. and McCormick, S. (2000). 'How FDI characteristics influences subsidiary trade patterns: The case of Ireland. Management International Review. 40 (3), pp. 203230.

Ekholm, K. E, Forslid, R. and Markusen, J. R. (2003). 'Export-platform foreign direct investment', Working Paper 9517,NBER Working Paper Series, Massachusetts.

Hanson, G. H., Mataloni, R. J. and Slaughter, M. J. (2001). 'Expansion strategies of U.S. multinational firms'. In Rodrik, D. and Collins, S. (Eds.), Brookings Trade Forum.

Hanson, G. H., Mataloni, R. J. and Slaughter, M. J. (2003). 'Vertical production networks in multinational firms’. Working paper 9723. NBER Working Paper Series, Massachusetts.

Kogut, B. and Zander, U. (1993). 'Knowledge of the firm and the evolutionary theory of the multinational corporation', Journal of International Business Studies, 24, pp. 625-645.

Markusen, J. R. (2002). Multinational Firms and the Theory of International Trade. The MIT Press. 
Markusen, J. R., and Maskus, K. E., (2002). 'A unified approach to intra-industry trade and foreign direct investment'. In: Lloyd, P. J. and Lee, H.-H. (Eds.), Frontiers of Research in Intra-industry Trade. Palgrave Macmillan.

Meyer, K. (2001). 'International business research on transition economies', in: Rugman, A. M. and Brewer, T. L. (Eds), The Oxford Handbook of International Business. Oxford University Press. Oxford.

Nielsen, J. U.-M. and Pawlik, K. (2004). 'Locally- versus export oriented production. An analysis of foreign capital in Poland 1993-2002', Working Paper. 04-4. Department of International Business, Aarhus School of Business, Denmark.

OECD (2001). Classification of High Technology Products and Industries, DSTI/EAS/IND/STP (91)1, Paris.

Otte, T. (2003). 'Renumeration of management in Polish companies', n Stüting; H.-J., Dorow, W., Claassen, F. and Blazejewski, S. (Eds), Change management in transition economies. integrating corporate strategy, structure and culture. Palgrave, Macmillan, Hamshire and New York.

Paldam, M. (2002). Udviklingen i Rusland, Polen og Baltikum. Lys Forude efter Andringen af det Økonomiske System, Aarhus Universitetsforlag.

Siddhartan, N. S. and Nollen, S. (2004). 'MNE affiliation, firm size and exports revisited: A study of information technology firms in India', The Journal of Development Studies. 40 (6), pp. 146-168.

Slaughter, M. J. (2003). 'Host-country determinants of U.S. foreign direct investment into Europe', http://www.dartmouth.edu/ mjs/Papers/Kap01_Slaughter.pdf

Teece, D. J. (1977). 'Technology transfer by multinational firms - The resource cost of transferring technological know-how', Economic Journal, 87, pp. 242-61.

UNCTAD (1999), World Investment Report 1999 - Foreign Direct Investment and the Challenge of Development. United Nations, New York and Geneva.

Yeaple, S. R. (2003). 'The complex integration strategies of multinationals and cross country dependencies in the structure of foreign direct investment', Journal of International Economics, 60 (2), pp.293-314 


\section{Appendix}

Table A1. Correlation tables 1993-2002

\begin{tabular}{|c|c|c|c|c|c|c|c|}
\hline & EXPORT & IMPORT & WAGE & LAB & INVEST & CONT & SCALE \\
\hline EXPORT & 1 & & & & & & \\
\hline IMPORT & 0.86 & 1 & & & & & \\
\hline WAGE & -0.28 & -0.20 & 1 & & & & \\
\hline LAB & 0.58 & 0.46 & -0.51 & 1 & & & \\
\hline INVEST & 0.10 & 0.31 & -0.10 & 0.14 & 1 & & \\
\hline CONT & 0.10 & 0.11 & 0.16 & -0.14 & 0.03 & 1 & \\
\hline SCALE & -0.11 & -0.07 & 0.49 & -0.21 & -0.04 & -0.10 & 1 \\
\hline
\end{tabular}

Source: Own calculation.

Table A2. Correlation tables 1993-1997

\begin{tabular}{|c|c|c|c|c|c|c|c|}
\hline & EXPORT & IMPORT & WAGE & LAB & INVEST & CONT & SCALE \\
\hline EXPORT & 1 & & & & & & \\
\hline IMPORT & 0.84 & 1 & & & & & \\
\hline WAGE & -0.38 & -0.28 & 1 & & & & \\
\hline LAB & 0.58 & 0.47 & -0.59 & 1 & & & \\
\hline INVEST & 0.04 & 0.42 & -0.11 & 0.15 & 1 & & \\
\hline CONT & 0.06 & 0.10 & 0.10 & -0.11 & 0.08 & 1 & \\
\hline SCALE & -0.12 & -0.10 & 0.25 & -0.21 & -0.04 & 0.04 & 1 \\
\hline
\end{tabular}

Source: Own calculation.

Table A3. Correlation tables 1998-2002

\begin{tabular}{|c|c|c|c|c|c|c|c|}
\hline & EXPORT & IMPORT & WAGE & LAB & INVEST & CONT & SCALE \\
\hline EXPORT & 1 & & & & & & \\
\hline IMPORT & 0.90 & 1 & & & & & \\
\hline WAGE & -0.37 & -0.21 & 1 & & & & \\
\hline LAB & 0.61 & 0.45 & -0.53 & 1 & & & \\
\hline INVEST & -0.11 & -0.05 & -0.13 & -0.01 & 1 & & \\
\hline CONT & 0.14 & 0.17 & -0.00 & -0.07 & -0.01 & 1 & \\
\hline SCALE & -0.13 & -0.06 & 0.57 & -0.24 & -0.08 & -0.23 & 1 \\
\hline
\end{tabular}

Source: Own calculation. 


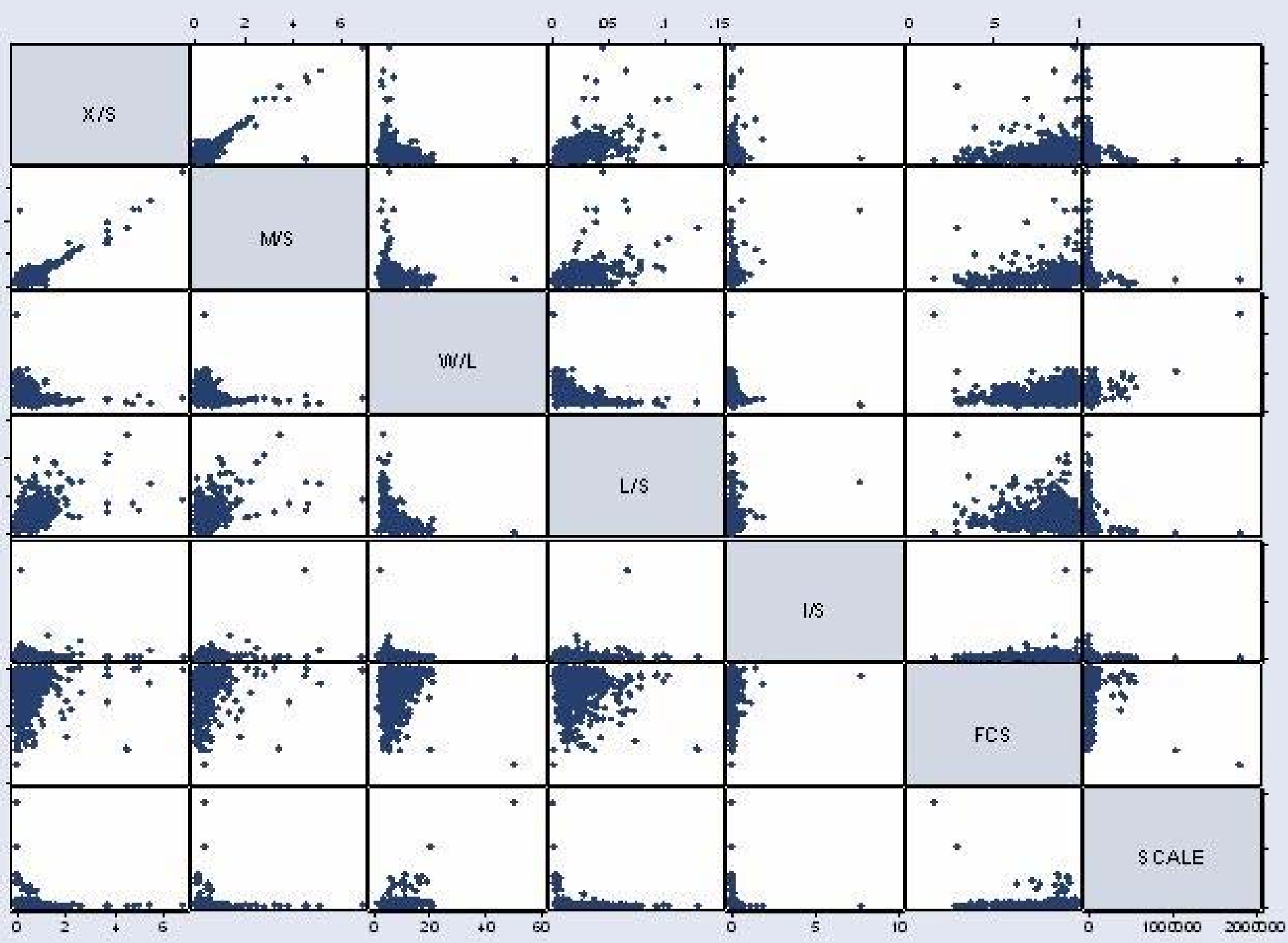


ISBN 87-7882-076-6

DEPARTMENT OF MANAGEMENT AND INTERNATIONAL BUSINESS

Aarhus School of Business

Fuglesangs Allé 4

DK-8210 Aarhus V - Denmark

Tel. +4589486688

Fax +4589486125

www.asb.dk 